\title{
Effects of Mulch and Irrigation System on Sweet Onion: II. The Epidemiology of Center Rot
}

\author{
R.D. Gitaitis ${ }^{1}$ \\ Department of Plant Pathology, Coastal Plain Experiment Station, University of Georgia, Tifton, GA \\ 31793-0748 \\ R.R.Walcott \\ Department of Plant Pathology, University of Georgia, Athens, GA 30602 \\ H.F. Sanders \\ Department of Plant Pathology, Coastal Plain Experiment Station, University of Georgia, Tifton, GA \\ 31793-0748
}

L. Zolobowska

Department of Genetics, University of Gent, Gent, Belgium

\author{
J.C. Diaz-Perez ${ }^{2}$ \\ Department of Horticulture, CPES, University of Georgia, Tifton, GA 31793-0748
}

Additional Index words. Allium cepa, Pantoea ananatis, plant disease, bacteria

\begin{abstract}
Aвstract. Mulch (black plastic, wheat straw, or bare ground) and irrigation (drip or overhead sprinkler) treatments were evaluated for their effect on center rot of onion (Allium cepa L.), caused by the bacterium Pantoea ananatis, over the course of two seasons. Irrigation type had no effect on center rot incidence or severity in either year. In contrast, center rot development was delayed by 7 to 14 days on onions grown in straw mulch or bare ground compared to those in black plastic. Straw mulch resulted in later harvest dates and was associated with reduced levels of center rot. In contrast, black plastic increased disease incidence and hastened the onset of the epidemic. The spatial distribution of disease incidence in both years indicated the presence of a primary disease gradient. At harvest, infected plants were segregated by treatment and by duration of infection [based on disease ratings taken from the time of first symptom expression (beginning at 110 to 120 days after transplanting and then every 5 to 10 days until harvest)]. Early- vs. lateinfected plants had no significant effect on yield (bulb weight). However, symptom expression in terms of the number of days after planting was significantly correlated with a disease severity index. Amount of rot in bulbs from plants displaying their first symptoms only 1 to 2 days before harvest (late-season infection) was not significant from rot levels in control bulbs at harvest. However, at 4 weeks after harvest, onions from plants with late-season infections exhibited significantly more rot in storage compared to the control.
\end{abstract}

Center rot of onion (Allium cepa L.), caused by the bacterium Pantoea ananatis (Serrano) Mergaret, accounted for significant losses when it was first observed near Vidalia, Ga. in 1997 (Gitaitis and Gay, 1997). Symptoms are similar to those of soft rot (Mohan, 1995), caused by Erwinia carotovora (Jones) Bergey et al., and include pale gray to white lesions with water-soaked margins that extend the length of the leaf. In time, lesions may darken to a light-brown color, darker gray or remain white (Gitaitis and Gay, 1997). Onset of symptoms usually occurs on only one or two leaves in the center of the affected plant. At later stages, all leaves wilt and become bleached. In time, infections can proceed down the leaf and neck and bacteria colonize bulb tissues. Although P. ananatis lacks pectinolytic enzymes, secondary microbes frequently colonize infected bulbs, which results in tissue liquefaction and a foul odor. In addition to onion, the bacterium has been reported as a pathogen of cantaloupe (Bruton et al., 1991), eucalyptus (Coutinho et al., 2002), honeydew melons

Received for publication 19 Feb. 2003. Accepted for publication 29 Oct. 2003. Funding for this research was provided by the Vidalia Onion Committee and by the USDA-CSREES Grant 99-34389-7437 "Integrated Disease Management to Improve the Quality of Sweet Onions in Georgia." Mention of trade names in this publication does not imply endorsement by the University of Georgia of products named, nor criticism of similar ones not mentioned.

'To whom reprint requests should be addressed; e-mail Gitaitis@tifton.uga.edu. ${ }^{2}$ Also affiliated with the Department of Plant Pathology, Coastal Plain Experiment Station, University of Georgia, Tifton, GA 31793-0748.
(Wells et al., 1987), muskmelon (Bruton et al., 1986), pineapple (Lim, 1986), sudan grass (Azad et al., 2000) and sugarcane (Elliott, 1951). It also has been associated with graywall of tomato (Stall et al., 1969).

Adisease, caused by P.agglomerans (synonymous with Erwinia herbicola) and described in South Africa in 1981, has similar symptomology (Hattingh and Walters, 1981). P. agglomerans and $P$. ananatis can be differentiated by several biochemical and physiological tests including the ability to produce indole, nitrate reductase, phenylalanine deaminase and acid in inositol, cellobiose, melibiose, and glycerol (Holt, 1977). Since P. agglomerans and P. ananatis are so similar (Mergaert et al., 1993) and some of the onion varieties affected in 1997 were grown from seed produced in South Africa, we speculated that the disease may have been introduced via contaminated seed (Walcott et al., 2002). Furthermore, first-time and recent reports of center rot in Colorado (Schwartz and Otto, 2000) and Michigan (M. Hausbeck, personal communication) also might be explained by dissemination through infested seed, and recently, we demonstrated that $P$. ananatis could be seedborne in onion (Walcott et al., 2002).

However there also is presumptive evidence that $P$. ananatis survives locally, as species-specific bacteriophage were recovered from lakes in the southern United States (Eayre et al., 1995). Since reproduction of bacteriophage are dependent upon their bacterial host, this is indirect evidence of the presence of the bacterium. 
Further evidence that $P$. ananatis survives locally was provided when the bacterium was detected as a resident epiphyte on 22 weed species as well as Bermuda grass (Cynodon dactylon), cowpea (Vigna unguiculata) and soybean (Glycine max) (Gitaitis et al., 2002a). Finally, we isolated the bacterium as a member of the gut microflora of thrips (Gitaitis et al., 2002b; Wells et al., 2002).

Typically, strategies to control phytopathogenic bacteria include the exclusion and eradication of initial inoculum by sanitation. According to Van der Plank (1963), benefits of disease control by sanitation are affected by the sanitation ratio (total inoculum / percent remaining inoculum after sanitation), the infection rate $(r)$ of the pathogen, and time or duration of favorable conditions for disease development. Sanitation delays the onset of an epidemic but does not reduce the rate. Unfortunately, once $99.9 \%$ of the inoculum is destroyed, the effort of reducing inoculum an additional 1000-fold only doubles the gain achieved (Van der Plank, 1963). Therefore, the exclusion and eradication of pathogens with a high $r$, such as phytopathogenic bacteria, have to be nearly perfect to achieve control. Control by sanitation is difficult to achieve when there is only one source of inoculum, but in the case of center rot it appears to be even more of a challenge as three sources of inoculum may exist, namely, seed, thrips and weeds.

Our goal is to develop an integrated strategy for the control of center rot. In addition to developing a seedborne assay and studying the role of weeds and thrips (Gitaitis et al. 2002a; Walcott et al., 2002; Wells et al., 2002), we investigated the effect of different cultural practices that would target either the onset of the epidemic or reduce the rate of disease development. Two cultural practices employed to control diseases are the use of mulch (Brown et al., 1989; Glass et al., 2001) and irrigation management (Bell et al., 1998; Teviotdale et al., 1989). Mulch has been used to control some diseases by repelling insect vectors (Greenough et al., 1990), but mulch may also provide disease control by reducing contact with inoculum (Brown et al., 1989). Water-splashing by rain or overhead irrigation is a primary mechanism of secondary spread of foliar pathogens. Therefore, elimination of free water could reduce disease spread and development. Here, we report the results from a two-year study in which we investigated different types of mulch and irrigation, that theoretically reduced splash-dispersal of phytopathogenic bacteria, and the effects they had on the development of center rot of onion.

\section{Materials and Methods}

The experiments were conducted at the University of Georgia's Blackshank Farm (BSF), at the Coastal Plain Experiment Station, Tifton, Ga. Experiments were conducted during the 1999-2000 and 2000-2001 seasons.

The soil at the BSF was a Tifton Sandy Loam soil (a fine loamy, silicious thermic Plinthic Paledults) with a $\mathrm{pH}$ of 6.5 to 6.8. Soils in plot areas were turned with a moldboard plow and harrowed. Raised plant beds were formed with a rototiller and bedshaper. Transplants of 'Sweet Vidalia' onion were planted $0.14 \mathrm{~m}$ apart within rows on beds having four rows, with a 0.23 m separation between rows. Transplant dates were 2 Dec. 1999 and 6 Dec. 2000. Treatments were arranged in a split-plot design with subplots being replicated four times in a randomized complete block design. Main plots consisted of overhead sprinkler irrigation or drip irrigation and subplots of black plastic film mulch (38 $\mu \mathrm{m}$ thick), wheat straw mulch, or bare ground. Each treatment consisted of three four-row beds $15 \mathrm{~m}$ in length, with a 1.8-m separation between the centers of adjacent beds. Drip irrigation tape (Ro-Drip, Roberts Irrigation Products Inc., San Marcos, Calif.), with $20 \mathrm{~cm}$ emitter spacing, $1 \mathrm{~L} \cdot \mathrm{h}^{-1}$ emitter flow at $5631 \mathrm{~kg} \cdot \mathrm{m}^{-2}$ pressure, and $0.20-\mathrm{mm}$ wall thickness was buried $3 \mathrm{~cm}$ deep. Two lines of drip tape were used per bed and were placed midway between two rows of plants.

Alleys between blocks were $3.0 \mathrm{~m}$ in length. Oxyfluorfen (Dow AgroSciences, Indianapolis, Ind.) at $2.34 \mathrm{~L} \cdot \mathrm{ha}^{-1}$ was applied within $5 \mathrm{~d}$ of transplanting for weed control. All plots received preplant application of fertilizer, $5 \mathrm{~N}-4.4 \mathrm{P}-15 \mathrm{~K}$ and $18 \mathrm{~N}-20.2 \mathrm{P}-0 \mathrm{~K}$, applied at $1120 \mathrm{~kg} \cdot \mathrm{ha}^{-1}$ and $146 \mathrm{~kg} \cdot \mathrm{ha}^{-1}$, respectively. After transplanting, plants under sprinkler irrigation received side-dressing applications of $15 \mathrm{~N}-0 \mathrm{P}-14 \mathrm{~K} 112 \mathrm{~kg} \cdot \mathrm{ha}^{-1}$ at 4 and 8 weeks after transplanting (WAT), calcium nitrate at $123 \mathrm{~kg} \cdot \mathrm{ha}^{-1}$ (12 WAT) and $148 \mathrm{~kg} \cdot \mathrm{ha}^{-1}$ (12 WAT), and potassium nitrate at $26 \mathrm{~kg} \cdot \mathrm{ha}^{-1}(12 \mathrm{WAT})$ and $30 \mathrm{~kg} \cdot \mathrm{ha}^{-1}$ (14 WAT). Plants under drip irrigation were fertilized weekly through the drip tape with $15-0-14$ at $28 \mathrm{~kg} \cdot \mathrm{ha}^{-1}$ from 5 WAT to 12 WAT, calcium nitrate at $62 \mathrm{~kg} \cdot \mathrm{ha}^{-1}$ and potassium nitrate at $13 \mathrm{~kg} \cdot \mathrm{ha}^{-1}$ from 13 WAT to $15 \mathrm{WAT}$, and calcium nitrate at $31 \mathrm{~kg} / \mathrm{ha}$ and potassium nitrate at $6.5 \mathrm{~kg} \cdot \mathrm{ha}^{-1} 16 \mathrm{WAT}$.

Beginning in February, foliar diseases caused by fungi were controlled with weekly applications of chlorothalonil (Syngenta, Basel, Switzerland) at $1.75 \mathrm{~L} \cdot \mathrm{ha}^{-1}$ alternating with iprodione (Aventis, Strasbourg, France ) at $2.24 \mathrm{~kg} \cdot \mathrm{ha}^{-1}$ every third week. At the first appearance of center rot symptoms, $\approx 110$ to $120 \mathrm{~d}$ after transplanting (DAT), a colored flag on a wire stem was placed adjacent to each symptomatic plant in the center bed of a three-bed plot. Ratings were made every 5 to $10 \mathrm{~d}$ and different colored flags were used for each rating period. At harvest, 3-mlong sections were randomly selected within the $15 \mathrm{~m}$ length of each treatment beginning or ending within a minimum of 5 $\mathrm{m}$ from the end of each plot. Onions were undercut $48 \mathrm{~h}$ before harvest and onion tops were allowed to field-cure. Onions were hand-harvested and roots and tops were clipped. In 2000, onions were harvested on 20 Apr., 28 Apr., and 5 May for black plastic, bare ground and straw mulch treatments, respectively. In 2001, onions were harvested on $23 \mathrm{Apr}$. for black plastic and on 3 May for bare ground and straw mulch treatments. The weight, size and grade of the bulbs were recorded for each treatment. In 2000, 25 bulbs from each grading period were split in half to evaluate interior bulb health after 0,2 , and 4 weeks of storage under dry conditions and ambient temperatures $\left(21\right.$ to $\left.29^{\circ} \mathrm{C}\right)$. Bulbs were rated on a 0 to 5 scale with 0 being no rot and 5 equal to $100 \%$ rot. A disease severity index [DSI $=($ sum of bulbs with rot $\times$ rating)/total number of bulbs] was calculated for each infection period. Due to lower levels of disease in 2001, sufficient quantities of bulbs from each rating period could not be obtained for data analysis.

Daily amounts of rain (cm) and high and low temperatures $(\mathrm{C})$ were obtained for Tift County, Ga., from the Georgia Automated Environmental Monitoring Network (http: //www.griffin.peachnet.edu/bae). Growing degree days (GDD) were calculated using a standard formula and a base temperature of $5^{\circ} \mathrm{C}$ [GDD $=($ daily high - daily low $\left.) / 2-5\right]$.

Data were analyzed by analysis of variance, pairwise multiple comparison procedures (Tukey test), linear regression, and student's $t$ test. In addition, disease progress curves were transformed and analyzed for best fit to the exponential, Gompertz, linear, logistic, and monomolecular models using Epimodel (Nutter and Parker, 1997). This was done to determine the effects of the mulch and irrigation treatments on the rates of center rot development. 


\section{Results}

Type of irrigation had little impact on incidence of center rot, whereas significant effects were observed for mulch type (Fig. 1). Final disease incidence was greater in plants grown on black plastic and less for those on straw mulch (Fig. 1). In addition to disease incidence, the effects of mulch on onset of disease (Fig. 2), disease progress (Fig. 3) and on bulb quality at harvest and during storage were examined (Figs. 4 and 5). When compared to bare ground, the standard commercial practice, black plastic hastened the onset of center rot by $\approx 5 \mathrm{~d}$ in 2000 and by $\approx 15 \mathrm{~d}$ in 2001 (Fig.2). In contrast, straw mulch delayed the onset of center rot by $\approx 15 \mathrm{~d}$ in 2000 , but was not different from bare ground in 2001; however, straw mulch delayed the onset of center rot by $\approx 15 \mathrm{~d}$ when compared to black plastic in 2001 (Fig. 2).

Using epimodel (Nutter and Parker, 1997), the best fit for the epidemic in both 2000 and 2001 was with the exponential model. Using the regression statistics from the best-fit model, disease progress curves were plotted (Fig. 3). In both years the transformed (linearized) data indicated that mulch treatments had little impact on the rate of center rot development, i.e., slope of the line (Figs. 3A and 3B), although there was a slight reduction of rate for straw mulch in 2000.

Primary disease gradients occurred within the field in both 2000 and 2001 (Fig. 6). The gradient was much steeper in 2000 when disease pressure was greater, but in both years the gradients ran from north to south and did not flatten beginning from the time of the first appearance of center rot until time of harvest. From 15 March (approximate starting date of the center rot epidemic) until harvest there were 17 and 15 rain events in 2000 and 2001, respectively. Rainfall from 15 Mar. to 5 May (approximate time span of the center rot epidemics) was 13.8 and $15.4 \mathrm{~cm}$ in 2000 and 2001, respectively. In 2000, from the time of first symptom expression to harvest, the mean daily high temperature was 24 ${ }^{\circ} \mathrm{C}$, the mean daily low temperature was $11.6^{\circ} \mathrm{C}$, and the range was 1 to $30^{\circ} \mathrm{C}$. In 2001 , from the time of first symptom expression to harvest, the mean daily high temperature was $22.9^{\circ} \mathrm{C}$, the mean daily low temperature was $11.8^{\circ} \mathrm{C}$, and the range was 3 to $30^{\circ} \mathrm{C}$. GDD between the time of first symptom expression

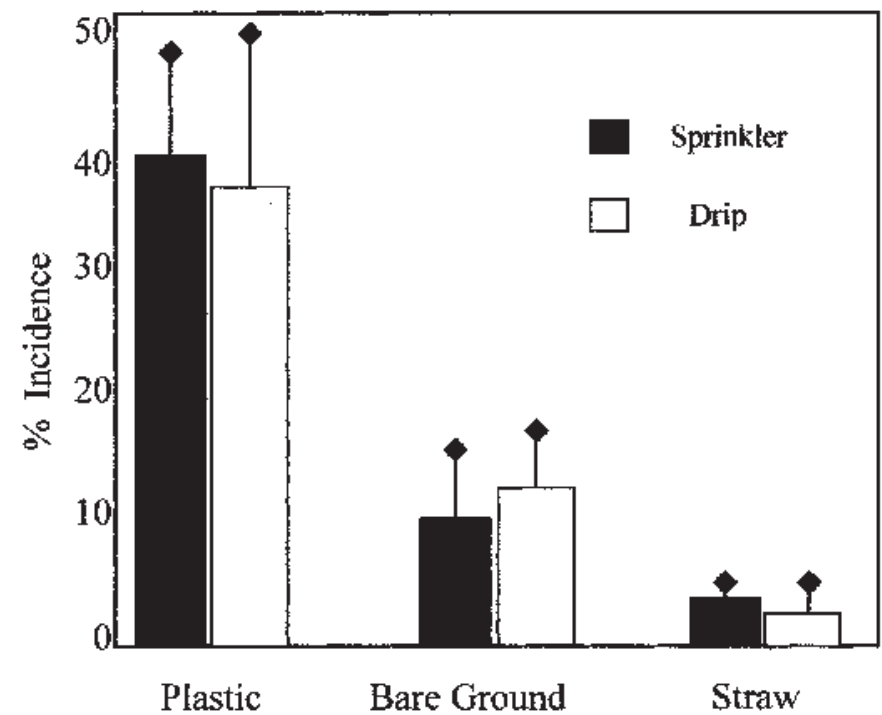

Fig. 1. Center rot of onion incidence in three mulch treatments and two irrigation types in 2000. Data analyzed by ANOVA and pairwise multiple comparison procedures (Tukey test). Each bar represents mean disease incidence for four replications of the experiment and the lines indicate the standard deviation of the means.
( $\approx 15$ Mar.) and harvest for 2000 and 2001 were 64.8 and 27.1, respectively.

There was little effect of center rot on yield. Although mean bulb weights ranged from $313 \mathrm{~g}$ for onions infected 120 DAT to $349 \mathrm{~g}$ for onions infected 155 DAT, the differences were not significant. However, center rot had a significant impact on bulb quality, as the longer a plant was infected in the field, the greater the disease severity index for the bulb (Fig. 4). This was true for all plants with center rot except those that became infected 1 to $2 \mathrm{~d}$ before harvest. Typically, in late-infected plants only one leaf (usually the center leaf) had symptoms. At harvest, bulb quality of late-infected plants was not significantly different from those of plants without center rot symptoms (Fig. 5). However, significantly higher levels of bulb rot were observed in late-infected plants after 4 weeks in storage (Fig. 5).

\section{Discussion}

Typically, bacteria causing foliar diseases are disseminated by splash dispersal and infections require free water. However,
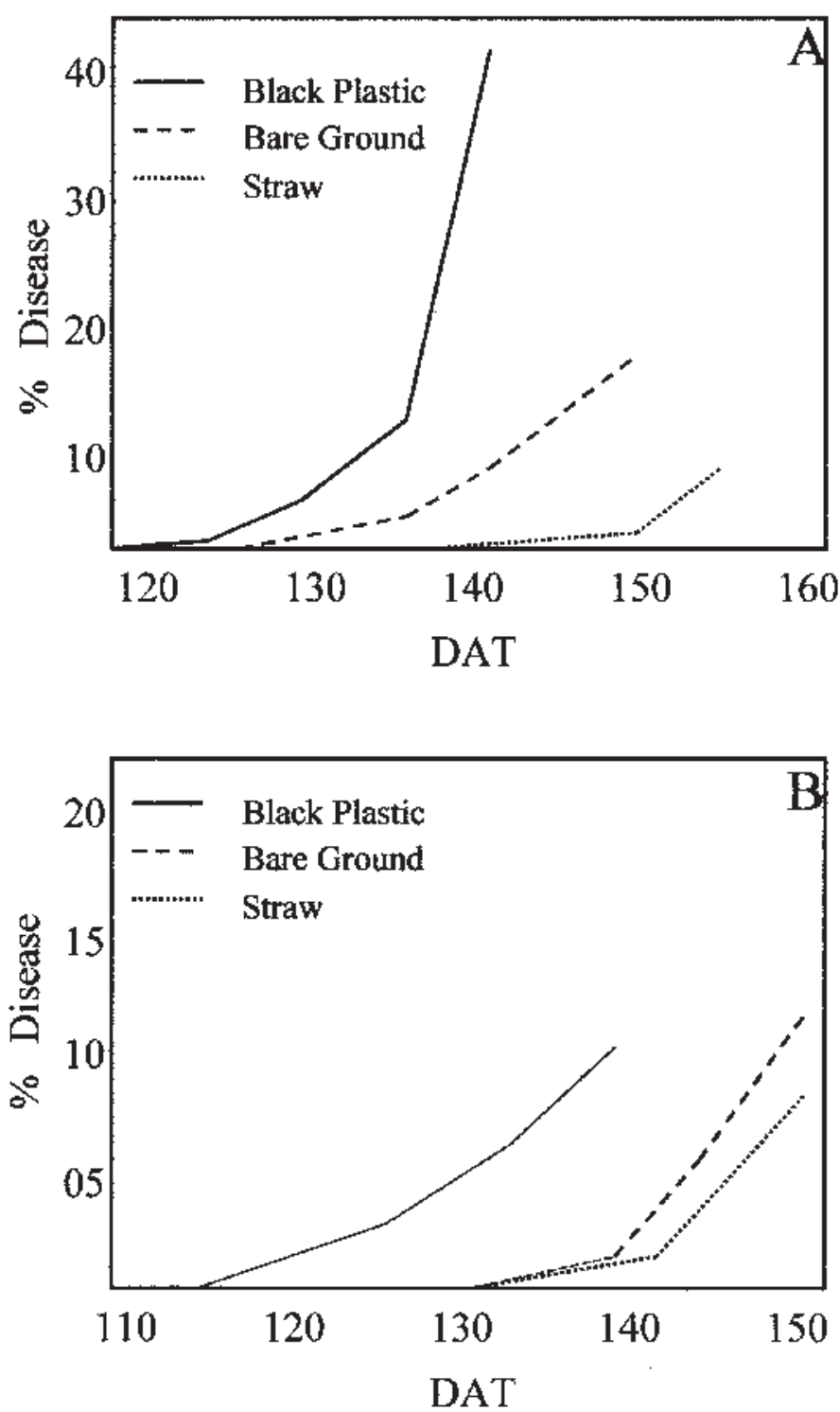

Fig. 2. Effect of black plastic mulch, straw mulch and bare ground on the onset and development of center rot of onion over time [days after transplanting (DAT)] in 2000 (A) and 2001 (B) at BSF site in southern Georgia. 
our results indicate that drip irrigation had no significant impact on center rot development when compared to overhead sprinkler irrigation (Fig.1). This was unexpected since the initial stages of center rot include a foliar blight. The lack of disease reduction by drip irrigation leads us to speculate that either rain events occurred in a timely manner to enhance disease and negate the potential benefit of drip irrigation for disease control, or free moisture is not required for secondary dissemination and infection by this pathogen. There were 17 and 15 rain events from 15 Mar. to harvest in 2000 and 2001, respectively; and these may have been sufficient to offset benefits due to drip irrigation. If this were true however, one would have expected equal or higher levels of disease in 2001 because there were $13.8 \mathrm{~cm}$ and $15.4 \mathrm{~cm}$ of rain in 2000 and 2001, respectively. Since there was substantially less disease in 2001 and since there was no benefit from drip irrigation, it is unlikely that free water is required to disseminate this pathogen. Furthermore, our recent finding of the association of $P$. ananatis with tobacco thrips, Frankliniella fusca, (Gitaitis et al., 2002b; Wells et al., 2002) lends support to the theory that secondary spread of the bacterium may be independent of rain events.

Although method of irrigation did not affect center rot, type of
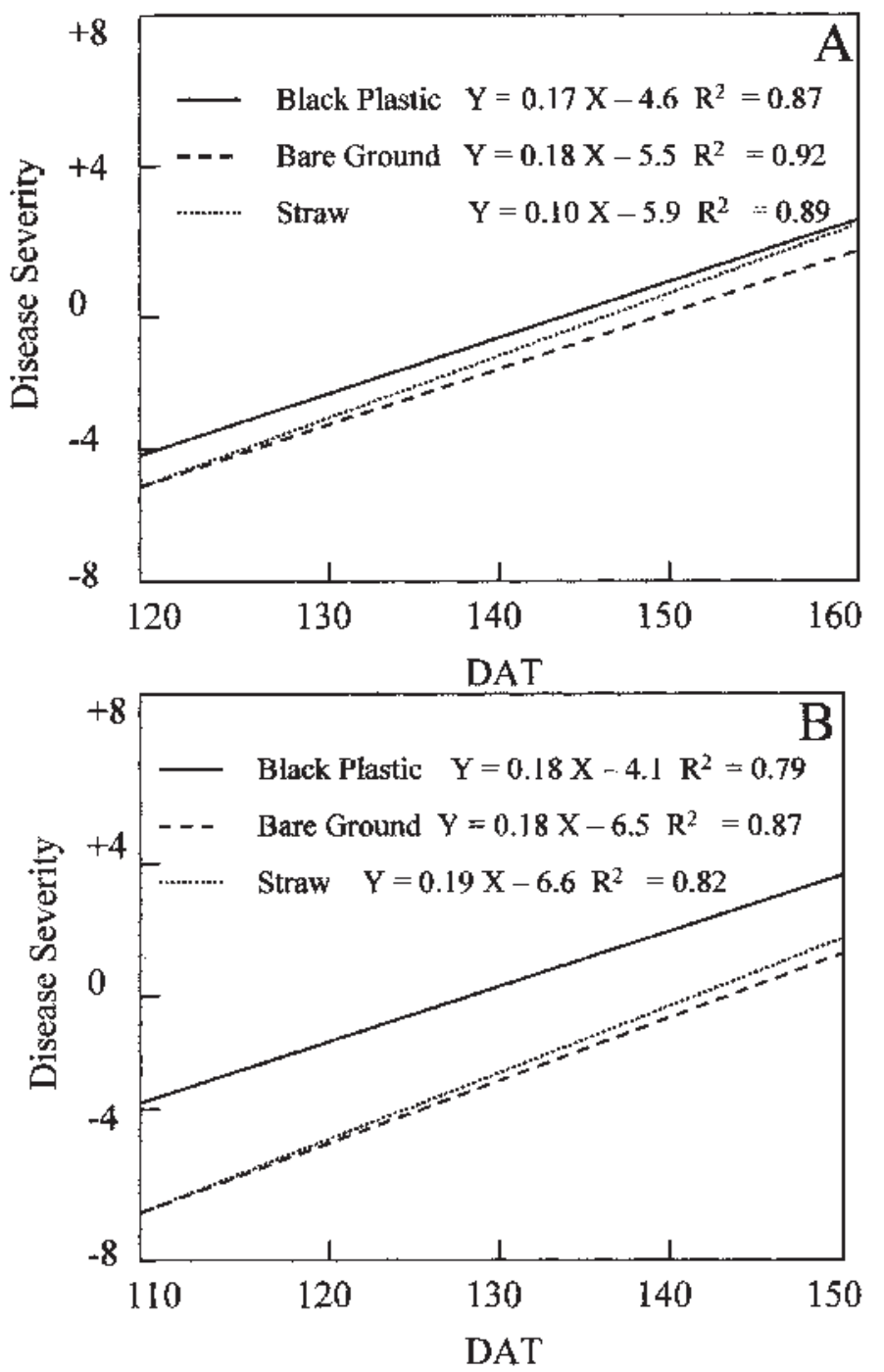

Fig. 3. Transformed data (exponential model) of percent center rot of onion over time [days after transplanting (DAT)] for black plastic, bare ground and straw mulch at the BSF site in 2000 (A) and 2001(B). mulch had a significant effect. Higher levels of center rot occurred on onions grown in black plastic in 2000 and in black plastic and bare ground in 2001. The hastening of the onset of center rot by black plastic may be due to the higher soil temperatures observed (Diaz Perez et al., 2003). Center rot has been considered a warmweather disease in onion because it generally occurs during the warmer months when onions are grown. The GDD values of 64.8 in 2000 , when the epidemic was quite severe, and only 27.1 in 2001, when disease levels were low, is evidence that center rot

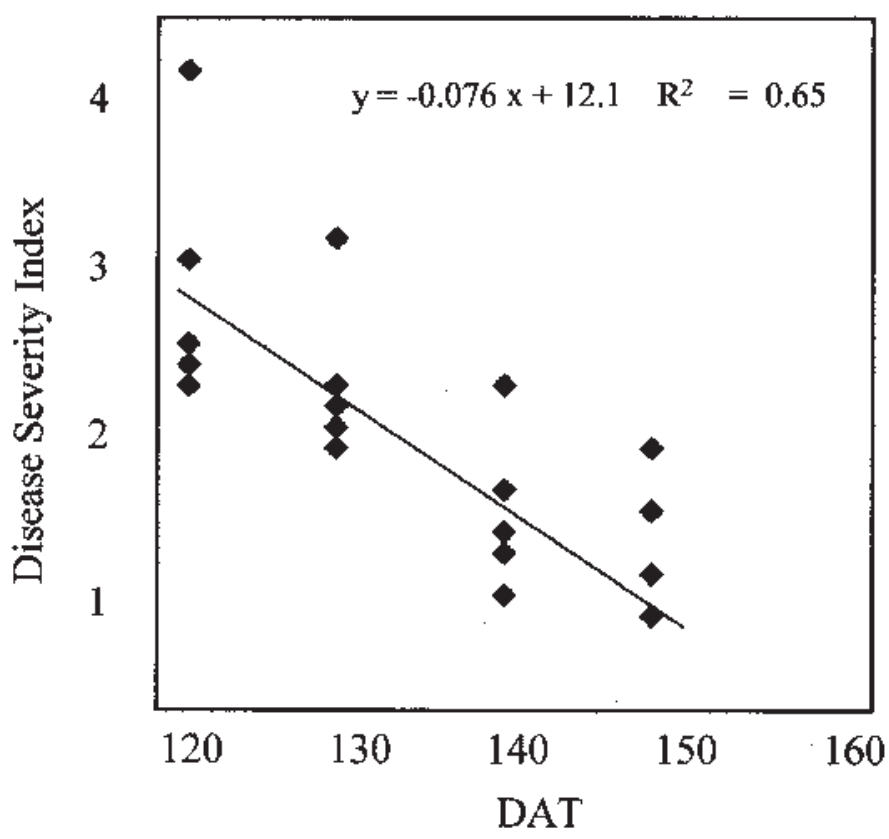

Fig. 4. Relationship of bulb quality at harvest to the duration of infection of plants in the field. Disease severity index of bulbs (sum of number of bulbs $\times$ disease rating [0 to 5$] /$ total number bulbs) regressed over time when plants became infected in the field [days after transplanting (DAT)].

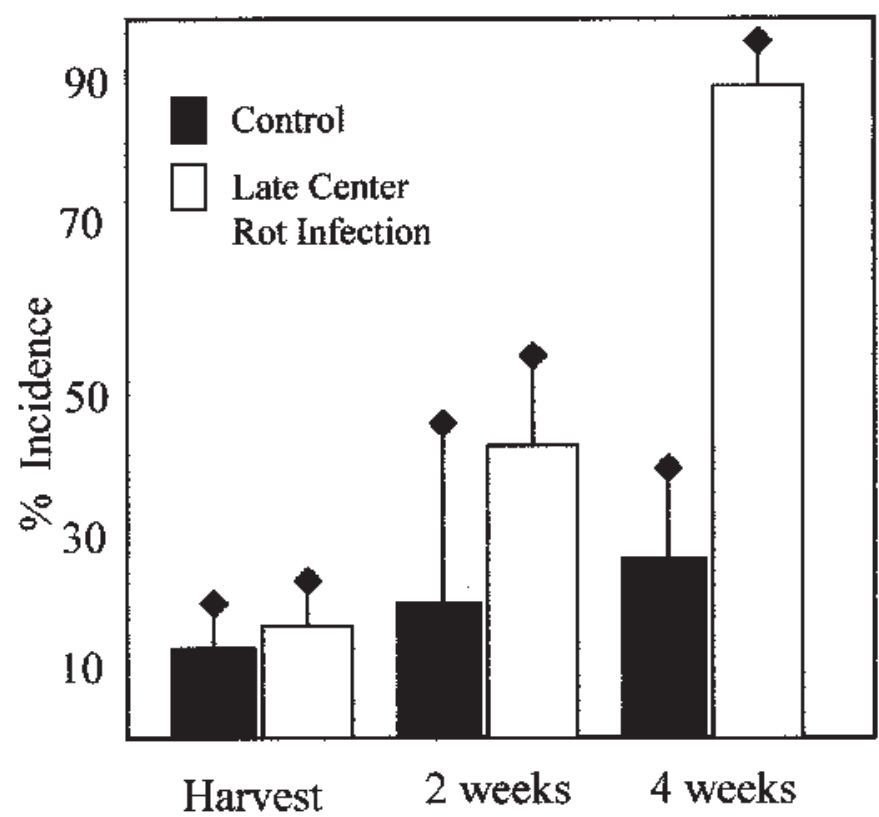

Fig. 5. Incidence of rot at harvest, after 2 and 4 weeks of storage in onion bulbs harvested from plants with one infected leaf occurring within $24 \mathrm{~h}$ of harvest (late center rot infection) or healthy (control) plants from BSF site. Data were analyzed by student's $t$ test. Each bar represents percent disease incidence of diseased onion bulbs for four replications of the experiment and the lines indicate the standard deviation of the means. 


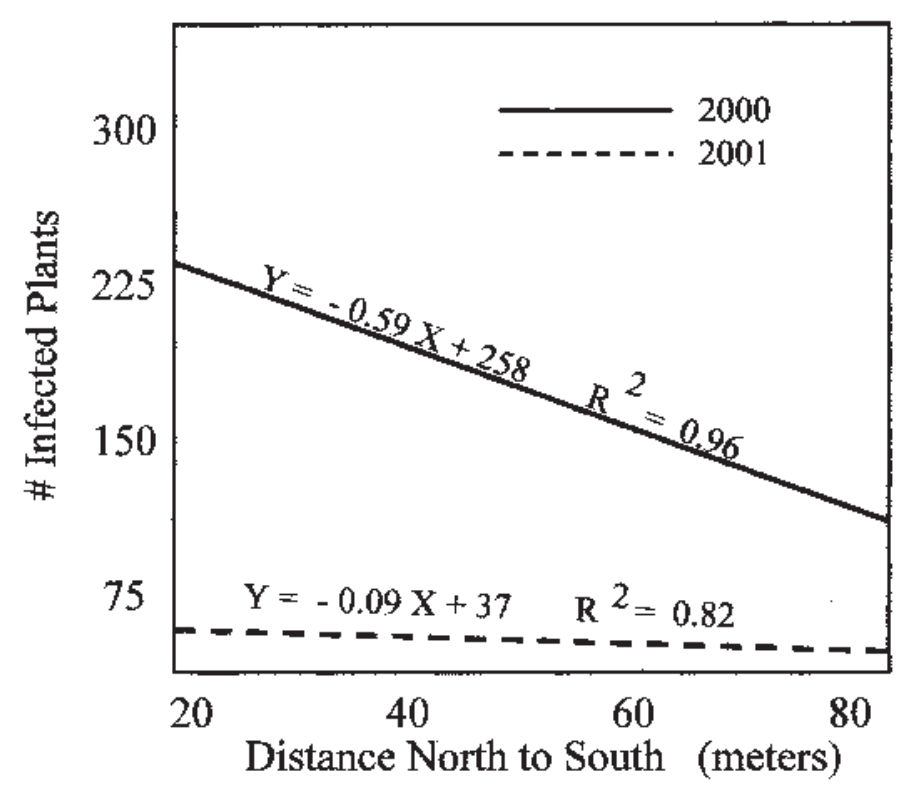

Fig. 6. Disease gradients based on the spatial distribution of final disease incidence of center rot in Vidalia onions in 2000 and 2001 at the BSF site in southern Georgia.

is favored by higher temperatures.

In both years, the least amount of disease occurred on onions in straw mulch. Final disease levels among mulch treatments could be accounted for primarily by a shift in the onset of the epidemic (Fig.2) and not changes in infection rate (Fig. 3), although a slight decrease in the infection rate was observed for onions in straw mulch in 2000. Also, in 2000, but not 2001, straw mulch accounted for a greater delay in onset of center rot compared to bare ground, whereas black plastic was associated with an increase in the onset of the epidemic in both years (Fig.2). Unfortunately, the benefits of disease control observed on straw mulch may be negated by lower yields and delayed harvest (Diaz-Perez et al., 2003).

The presence of a disease gradient generally implies that there is a local source of inoculum (Gitaitis et al., 1978; Gitaitis et al., 1998; Gregory, 1968). We previously demonstrated that $P$. ananatis could be seedborne (Walcott et al., 2002), reside as an epiphyte on weeds (Gitaitis et al., 2002a), and survive in the gut of thrips (Wells et al., 2002). A gradient running north to south could indicate weeds as a source of inoculum in the northern end of the plots, thrips migrating into the fields from the north, or both. We previously demonstrated the occurrence of primary dispersal gradients from weeds for bacterial blight of corn (Gitaitis et al., 1978). Likewise, primary dispersal gradients were observed in commercial peppers with the disease tomato spotted wilt, caused by a thrips-vectored virus (Gitaitis, et al., 1998). As the role of thrips and weeds in the epidemiology of this disease are studied further, evaluating the use of aluminum-colored mulch to repel thrips (Greenough et al., 1990) as a control measure for center rot may be warranted.

Although there were significant differences in yield due to treatments (Diaz-Perez et al., 2003), those differences could not be attributed to center rot. There were no significant differences in bulb weight among infected bulbs acquiring infections during the earliest to the latest rating periods. However, effects on bulb quality were observed. The number of days from first center rot symptom expression was significantly correlated with a disease severity index (Fig.4). Also, plants developing late infections of center rot immediately before harvest exhibited significantly higher levels of rot during storage, despite passing grade at harvest (Fig.5). This latent infection is a major problem for quality control in the onion industry, because it is impossible to grade onions on exterior bulb appearance alone. Splitting the bulbs at harvest indicated no difference in bulb quality between bulbs coming from healthy or recently diseased plants. Knowledge of the condition of the foliage before harvest, i.e., the presence of center rot symptoms, would provide information to predict whether center rot will reduce storability. However, it may be impractical in a typical commercial environment to rogue diseased plants by hand before harvest or to expect workers harvesting onions also to evaluate for disease symptoms on foliage of plants that have been uprooted and cured for a minimum period of 48 hours by exposure to the sun. Nevertheless, if consumer demand indicates a need, training of workers to rogue infected plants before harvest or rogue such plants during harvest may be justifiable in order to reduce losses in storage.

\section{Literature Cited}

Azad, H.R., G.J. Holmes, and D.A. Cooksey. 2000. A new leaf blotch disease of sudangrass caused by Pantoea ananas and Pantoea stewartii. Plant Dis. 84: 973-979.

Bell, A.A., L. Liu, B. Reidy, R.M. Davis, and K.V. Subbarao. 1998 Mechanisms of subsurface drip irrigation-mediated suppression of lettuce drop caused by Sclerotinia minor. Phytopathology 88:252-259.

Brown, J.E., C. Stevens, M.C. Osborn, and H.M. Bryce. 1989. Black plastic mulch and spunbonded polyester row cover as method of southern blight control in bell pepper. Plant Dis. 73:930-932.

Bruton, B.D., J. M. Wells, and G.E. Lester. 1986. Pathogenicity of Erwinia ananas muskmelons in Texas. Phytopathology 76:1136.

Bruton, B.D., J.M. Wells, G.E. Lester, and C.L. Patterson. 1991. Pathogenicity and characterization of Erwinia ananas causing a post harvest disease of cantaloupe fruit. Plant Dis. 75:180-183.

Coutinho, T.A., O. Preisig, J. Mergaert, M.C. Cnockaert, K.H. Riedel, J. Swings, and M.J. Wingfield. 2002. Bacterial blight and dieback of Eucalyptus species, hybrids, and clones in South Africa. Plant Dis. 86:20-25.

Diaz-Perez, J.C., W.M. Randle, G. Boyhan, R.R. Walcott, D. Giddings, D.Bertrand, H. Sanders, and R.D.Gitaitis. 2003. Effect of mulch and irrigation system on sweet onion: I. Bolting, plant growth, and bulb yield and quality. J. Amer. Soc. Hort. Sci. (in press).

Eayre, C.G., J.A.Bartz, and D.E. Concelmo. 1995. Bacteriophages of Erwiniacarotovora and Erwinia ananas isolated from freshwater lakes. Plant Dis. 79:801-804.

Elliott, C. 1951. Manual of bacterial plant pathogens. $2^{\text {nd }}$ ed. Chronica Botanica, Waltham, Mass.

Gitaitis, R.D., C.C. Dowler, and R.B. Chalfant. 1998. Epidemiology of tomato spotted wilt in pepper and tomato in southern Georgia. Plant Dis. 82:752-756.

Gitaitis, R.D. and J.D. Gay. 1997. First report of a leaf blight seed stalk rot, and bulb decay of onion by Pantoea ananas in Georgia. Plant Dis. 81:1096.

Gitaitis, R.D., R.E. Stall, and J.O. Strandberg. 1978. Dissemination and survival of Pseudomonas alboprecipitans ascertained by disease distribution. Phytopathology 68:227-231.

Gitaitis, R., R. Walcott, S. Culpepper, H. Sanders, L. Zolobowska, and D. Langston. 2002a. Recovery of Pantoea ananatis, causal agent of center rot of onion, from weeds and crops in Georgia, USA. Crop Protection 21:983-989.

Gitaitis, R.D., M.L. Wells, F.H. Sanders, D.G. Riley, and R.R. Walcott. 2002b. Association of the bacterium Pantoea ananatis with tobacco thrips, Frankliniella fusca. Phytopathology 92:S149.

Glass, J.R., K.B. Johnson, and M.L. Powelson. 2001. Assessment of barriers to prevent the development of potato tuber blight caused by Phytophthora infestans. Plant Dis. 85:521-528.

Greenough, D.R., L.L. Black, and W.P. Bond. 1990. Aluminum-surfaced 
mulch: an approach to the control of tomato spotted wilt virus in solanaceous crops. Plant Dis. 74:805-808.

Gregory, P.H. 1968. Interpreting plant disease dispersal gradients. Annu. Rev. Phytopathol. 6:189-212.

Hattingh, M.J. and D.F. Walters. 1981. Stalk and leaf necrosis of onion caused by Erwinia herbicola. Plant Dis. 65:615-618.

Holt, J.G. 1977. The shorter bergey's manual of determinative bacteriology. $8^{\text {th }}$ ed. Williams \& Wilkins Co., Baltimore, Md.

Lim, W.H. 1986. Bacterial diseases of pineapple. Rev. Trop. Plant Pathol. 2:127-140.

Mergaert, J., L. Verdancy, and K. Keister. 1993. Transfer of Erwinia ananas (synonym, Erwinia uredovora) and Erwinia stewartii to the genus Pantoea emend.as Pantoea ananas (Serrano 1928) comb. nov. and Pantoea stewartii (Smith 1898) comb. nov., respectively, and description of Pantoea stewartii subsp. indologenes subsp.nov. Intl. J. Syst. Bacteriol. 43:162-173.

Mohan, S.K. 1995. Soft rot, p. 32, In: H.F. Schwartz and S.K. Mohan (eds.). Compendium of onion and garlic diseases. APS Press, St. Paul, Minn.

Nutter, Jr., F.W. and S.K. Parker. 1997. Fitting disease progress curves using EPIMODEL, p. 24-28, In: L.J. Franci and D.A. Neher (eds.),
Exercises in plant disease epidemiology. APS Press, St. Paul, Minn.

Schwartz, H.F. and K. Otto. 2000. First report of a leaf blight and bulb decay of onion byPantoea ananatis in Colorado. Plant Dis. 84: 808.

Stall, R.E., L.J.Alexander, and C.B. Hall. 1969. Effect of tobacco mosaic virus and bacterial infections on occurrence of graywall of tomato. [Erwinia ananas]. Proc. Fla. State Hort. Soc. 81:157-161.

Teviotdale, B.L., R.M. Davis, J.P. Guerard, and D.H. Harper. 1989. Effect of irrigation management of sour skin of onion. Plant Dis. 73: 819-822.

Van der Plank, J.E. 1963. Plant diseases: Epidemics and control. Academic Press, New York.

Walcott, R.R., R.D. Gitaitis, A.C. Castro, F.H. Sanders, Jr., and J.C. DiazPerez. 2002. Natural infestation of onion seed by Pantoea ananatis, causal agent of center rot. Plant Dis. 86:106-111.

Wells, J.M., W.S. Sheng, M.J. Ceponis, and T.A. Chen. 1987. Isolation and characterization of strains of Erwinia ananas from honeydew melons. Phytopathology. 77:511-514.

Wells, M.L., R.D. Gitaitis, and F.H. Sanders. 2002. The association of tobacco thrips, Frankliniella fusca, (Thysanoptera: Thripidae) with two species of bacteria of the genus Pantoea. Ann. Entomol. Soc. Amer. 95:719-723. 